\title{
Plankton-pigment relationships in the Northwestern Mediterranean during stratification
}

\author{
Mikel Latasa, Marta Estrada, Maximino Delgado \\ Institut de Ciències del Mar (Institute of Marine Sciences), Passeig Nacional s/n, E-08039 Barcelona, Spain
}

\begin{abstract}
During May 1989, the composition of the phytoplankton community and the distribution of photosynthetic pigments was studied at a series of stations across the Catalan front (Northwestern Mediterranean). The water column presented a stratified structure, with a well-marked pigment maximum between 40 and $60 \mathrm{~m}$ depth. This maximum, which included chlorophylls $a, b$ and $c$ and several carotenoids, resulted from increased biomass of different phytoplankton taxa, as measured by epifluorescence and inverted microscope techniques, and from higher cellular content of most of the measured pigments (including chlorophylls and fucoxanthin derivatives). An exception was zeaxanthin, which showed a maximum at depth, but appeared to accumulate in Synechococcus spp. cells of the upper euphotic zone. A patch of high phaeophorbide concentration near the front was associated to elevated mesozooplankton abundance. Changes in pigment/cell ratios throughout the deep pigment maximum layer suggest that this is a zone of significant gradients in parameters affecting phytoplankton growth.
\end{abstract}

\section{INTRODUCTION}

During the stratification period, the water column of temperate and tropical seas shows a well-defined vertical pattern. The upper part of the euphotic zone receives high irradiance but is nutrient-depleted, while in deeper waters nutrients are available but illumination is poor (Dugdale 1967, Venrick et al. 1973). Typically, a chlorophyll maximum (deep chlorophyll maximum or DCM) occurs within the pycnocline, in the boundary between the 2 layers (Margalef et al. 1966, Anderson 1969, Hobson \& Lorenzen 1972, Cullen 1982, Estrada 1985). Under oligotrophic conditions, the DCM is closely associated with the nitracline, indicating the importance of upward nutrient transport (typical tropical structure of Herbland \& Voituriez 1979). The DCM is often, but not always, a deep biomass maximum (Beers et al. 1975, Cullen 1982). Many authors have reported marked changes between the composition of the planktonic community in the DCM and in the upper layers (Venrick et al. 1973, Cullen 1982, Furuya \& Marumo 1983, Estrada 1985). However, in other cases no significant differences were observed (Taniguchi \& Kawamura 1972), suggesting that a variety of mechanisms may be implicated in the formation and maintenance of the DCM, in relationship to geographical and seasonal differences.

Superimposed on qualitative and quantitative differences in the composition of the phytoplankton community, the environmental conditions experienced by the organisms in the different levels of the euphotic zone produce high variability in the distribution of photosynthetic pigments. In the DCM, the availability of nutrients and the low irradiances act together to increase the cellular content of pigments. In the shallower levels, nutrient limitation and high irradiances have generally the opposite effect (Kiefer et al. 1976, Banse 1977, Cullen 1982, Estrada 1985, Algarra \& Vaqué 1989).

Although there are a good number of taxonomic or pigment studies in DCM zones (Venrick et al. 1973, Gieskes et al. 1978, Furuya \& Marumo 1983, Takahashi \& Hori 1984, Estrada 1985, Estrada \& Salat 1989. Furuya 1990, Ondrusek et al. 1991) pigment information has been seldom coupled with taxonomic data (Jeffrey \& Hallegraeff 1980, Gieskes \& Kraay 1986). In addition, the importance of the picoplankton fraction could not be assessed in classical taxonomic works as a result of the lack of appropriate techniques. 
The Northwestern Mediterranean can be considered as an oligotrophic sea. However, it presents more or less localized eutrophic regions, associated to a variety of fertilization mechanisms. In the Catalan Sea (Fig. 1), 2 frontal zones, one in the peninsular side (the Catalan front) and another in the Balearic side (the Balearic front), have an important effect on the pelagic ecosystem. These structures appear to be in continuity with the corresponding fronts of the Liguro-provençal Sea (Estrada \& Margalef 1988).

This paper deals with the distribution patterns of autotrophic plankton and associated photosynthetic pigments across the Catalan front during the FRONTS 89 cruise carried out in March 1989. For the first time in this zone, HPLC techniques were applied to pigment determination. With this approach we focused the study on 2 objectives: (1) to estimate the importance of degradation pigments, especially at the DCM, and (2) to evaluate the contribution of taxonomic and physiological variability to the pigment composition throughout the water column.

\section{MATERIAL AND METHODS}

During the second leg of the FRONTS 89 cruise, 19 to 23 May 1989, several stations were occupied along a transect between the Barcelona coast and the Balearic Islands (Fig. 1).

At Stns B-1 to B-5, water was taken in a first cast at $10 \mathrm{~m}$ intervals between 0 and $80 \mathrm{~m}$ and at larger intervals down to $200 \mathrm{~m}$ (phytoplankton samples) or $400 \mathrm{~m}$ (physico-chemical analyses). Additional casts were made at Stns B-1 to B-4 to obtain water from 6 selected depths $(0,20,40,50,60$ and $80 \mathrm{~m})$ for chromatographic pigment analyses and for particulate organic $\mathrm{C}$ and $\mathrm{N}$ (POC and PON) determination in suspended matter

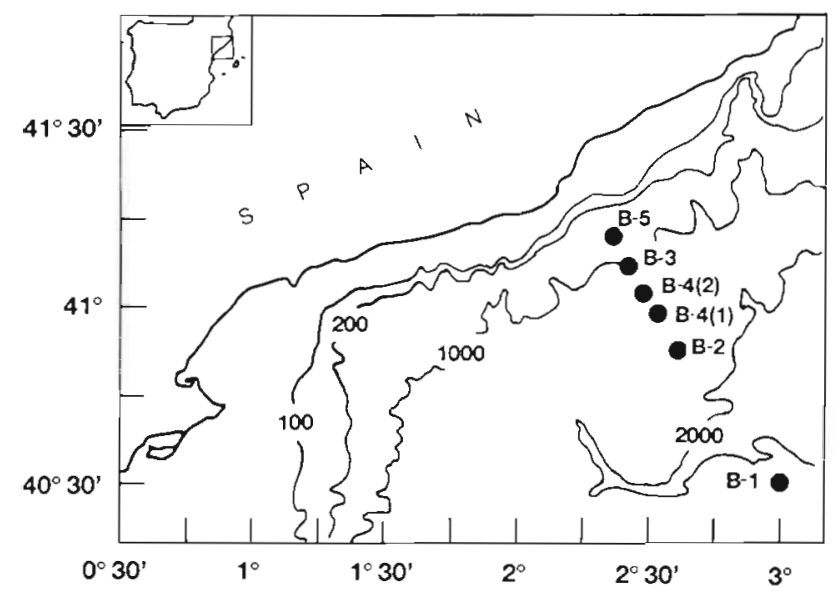

Fig. 1. Position of sampling stations, Northwestern Mediterranean Sea passing through, or retained by, a net of $200 \mu \mathrm{m}$ pore size (referred to as the $0-200 \mu \mathrm{m}$ and $>200 \mu \mathrm{m}$ size fractions respectively). Basic hydrographic data for the cruise are given in Varela \& Grup Fronts (in press).

Temperature readings were obtained from inverted thermometers attached to the hydrographic bottles of the first cast. Water samples for salinity determinations were obtained in the same cast and stored in hermetically capped Pyrex bottles for subsequent analysis in the laboratory using a Beckman salinometer.

Irradiance at 5 or $10 \mathrm{~m}$ intervals between surface and $70 \mathrm{~m}$ depth was measured at solar noon by means of a Li-Cor quantum meter provided with a $4 \pi$ cosine detector.

Pigment analysis. Samples for pigment analysis, consisting of 4 to 61 of water, were filtered through Whatman GF/F filters which were subsequently ground in $90 \%$ acetone. The analyses were carried out by means of an LKB HPLC system provided with LKB spectrophotometric (set at $440 \mathrm{~nm}$ ) and Perkin-Elmer LS-2 spectrofluorimetric (excitation at $450 \mathrm{~nm}$, emission between 600 and $800 \mathrm{~nm}$ ) detectors. A gradient programme was used to elute pigments from a $150 \mathrm{~mm}$ length, $5 \mu \mathrm{m}$ size particles, Spherisorb ODS-2 column. Eluent A consisted of $\mathrm{MeOH}: \mathrm{H}_{2} \mathrm{O}: \mathrm{PIC}(80: 10: 10)$ and eluent $\mathrm{B}$ of $\mathrm{MeOH}$ : acetone $(70: 30)$. PIC solution was a mixture of $1.5 \mathrm{~g}$ tetrabutylammonium acetate and 7.7 ammonium acetate adjusted to $\mathrm{pH} 7.1$ in $100 \mathrm{ml}$ water (Mantoura \& Llewellyn 1983). The concentrations of both eluents varied as follows: $0 \mathrm{~min}, 0 \% \mathrm{~B}$; $2 \mathrm{~min}, 10 \% \mathrm{~B} ; 7 \mathrm{~min}, 60 \% \mathrm{~B} ; 12 \mathrm{~min}, 80 \% \mathrm{~B} ; 14 \mathrm{~min}$ $100 \% \mathrm{~B} ; 30 \mathrm{~min}, 100 \% \mathrm{~B}$. This system was unable to separate lutein and zeaxanthin, but absorbance spectra of the common peak showed that it was mainly zeaxanthin. Typical absorbance chromatograms are shown in Fig. 2.

For pigment identification, peaks were collected at the column outlet, and their absorbance traces compared to those given in the literature (Foppen 1971, Abaychi \& Riley 1979, Mantoura \& Llewellyn 1983, Wright \& Shearer 1984, Wright \& Jeffrey 1987, Rowan 1989). Absorbance and fluorescence peak areas were measured with CRA-3 and CRA-1 Shimadzu integrators respectively. The quantification of pigments was carried out by means of standards obtained from unialgal cultures. The molar extinction coefficient of fucoxanthin was applied to $19^{\prime}$ hexanoyloxyfucoxanthin and $19^{\prime}$ butanoyloxyfucoxanthin. (hereafter hexanoyl and butanoyl) (Wright \& Jeffrey 1987), and a value of $\epsilon=250 \mathrm{l} \mathrm{g}^{-1}$ (recommended by Mantoura \& Llewellyn 1983) was used to calculate alloxanthin concentration. We could not obtain the absorbance spectra of the pigment which eluted before the chlorophylls, but due to its chromatographic position and the abundance of prymnesiophytes in the samples (see below) 

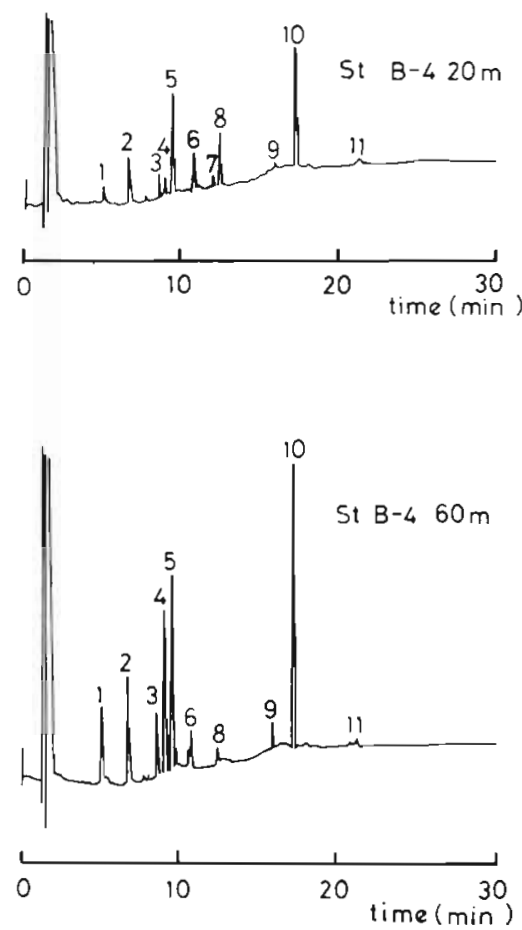

Fig. 2. Typical chromatograms of samples from 20 and $60 \mathrm{~m}$ depth. Peaks are identified as follows: (1) chl $c_{3}$, (2) chls $c_{1}$ (3) 19' butanoyloxyfucoxanthin, (4) fucoxanthin, (5) 19 hexanoyloxyfucoxanthin, (6) diadinoxanthin, (7) alloxanthin,

(8) zeaxanthin, (9) chl $b,(10) \mathrm{chl} a$, (11) $\beta$-carotene

we assumed it was chl $c_{3}$. What we consider chls $c$ could be, in fact, a mixture of chl $c_{1}$, chl $c_{2}$, and $\mathrm{Mg} \mathrm{2,4}$ divinyl pheoporphyrin $\mathrm{a}_{5}$ monomethyl ester $(\mathrm{Mg} 2,4 \mathrm{D})$ because all of them would co-elute at the same time.

Phaeophorbide calculations. The relationship between phaeophorbide concentration and production rate by herbivores at $\mathrm{Stn}$ B-4(1) (40 m depth), in which both phaeophorbide concentration and mesozooplankton biomass showed a marked maximum (Saiz et al. 1992), was explored applying the expression:

$$
g=(P I k) C^{-1}
$$

where $g=$ grazing rate $\left(\mathrm{d}^{-1}\right) ; P=$ phaeophorbide concentration (nmol $\left.\mathrm{l}^{-1}\right) ; \quad I=$ irradiance $\left(\mu \mathrm{E} \mathrm{m}^{-2} \mathrm{~d}^{-1}\right)$; $k=$ photodegradation constant $\left(\mathrm{m}^{2} \mu \mathrm{E}^{-1}\right)$; and $C=$ chlorophyll concentration ( $\mathrm{nmol} \mathrm{l}^{-1}$ ).

This equation is derived from the model of Welschmeyer \& Lorenzen (1985), assuming that chlorophyll and phaeophorbide concentrations are approximately in steady state for the time frame of reference (taken here as $1 \mathrm{~d}$ ), that grazers convert chlorophyll to phaeophorbide with $100 \%$ molar efficiency and that there is negligible sinking of faecal material. Under these conditions, the model of Welschmeyer \& Lorenzen (1985) postulates that phaeophorbide production by grazing herbivores equals phaeophorbide degradation by photooxidation. The values used for the parameters were $P=0.30 \mathrm{nmol} \mathrm{I}^{-1}, I=3.456 \mu \mathrm{E} \mathrm{m}^{-2} \mathrm{~d}^{-1}, C=$ $1.92 \mathrm{nmol} \mathrm{l}^{-1}$ (data from the measurements carried out at the station) and $k=3.73 \times 10^{-2} \mathrm{~m}^{2} \mathrm{E}^{-1}$ (according to SooHoo \& Kiefer $1982 \mathrm{~b}$, for light measurements made with a $4 \pi$ sensor).

Maximal amounts of phaeophorbide inside the bodies of mesozooplankton organisms were calculated multiplying an estimate of their total abundance by an estimate of the gut phaeophorbide a content per individual. The abundance estimate was obtained dividing the total PON ( $\mu$ g-at. $\mathrm{N}^{-1}$ ) in the $>200 \mu \mathrm{m}$ fraction (Saiz et al. 1992) by an average $N$ content per mesozooplankton organism $\left(0.28 \mu \mathrm{g}\right.$-at. $\mathrm{N}$ ind. $\left.{ }^{-1}\right)$ obtained from Båmstedt (1986). The average gut content of phaeophorbide a $\left(0.5 \mathrm{pmol}\right.$ ind. $\left.{ }^{-1}\right)$ was taken from the gut pigment determinations of Saiz et al. (1992) for Centropages typicus (an important component of the mesozooplankton community in the area). This approximation assumes that all the measured gut pigments were phaeophorbides.

Plankton data. Cyanobacteria Synechococcus spp. and autotrophic phytoplankton of the size classes $<2$, 2-5 and 5-10 $\mu \mathrm{m}$ (hereafter referred to as epifluorescence phytoplankton) were enumerated by epifluorescence, after fixation of $100 \mathrm{ml}$ water samples with $2.5 \%$ glutaraldehide and filtration on a $0.2 \mu \mathrm{m}$ Nuclepore filter. Phytoplankton species composition in the nano- and microplankton size ranges was examined by means of the inverted microscope technique (Utermöhl 1958), using $100 \mathrm{ml}$ aliquots preserved with Lugol's solution, which were allowed to settle in a composite chamber (Estrada \& Salat 1989). Many organisms could not be classified to the genus or species level and had to be lumped into categories such as 'flagellates'. It should be noted that small cells such as those in the flagellate group deteriorate in fixed samples, so that their concentration is likely to be underestimated by the inverted microscope methodology. The data set resulting from the inverted microscope observations will be, for simplicity, referred to as 'Utermöhl plankton'. Data on ciliate concentration were obtained from M. Palau (pers. comm.). Mesozooplankton biomass was assumed to be represented by the $>200 \mu \mathrm{m}$ PON fraction (Saiz et al. 1992).

Pigment:cell ratios. The vertical distribution of the cellular content of different pigments was estimated for each station from the ratio between the concentration of the pigment at each depth and the corresponding abundance of the main taxa or groups of taxa possessing it. Of course, due to differences in cell size and taxonomic composition, this procedure provides only a rough approximation. Since differences between stations were small relative to vertical changes, data 
from each depth were pooled to obtain an estimate of the vertical variability of the ratios.

The profiles of chl a were related to the sum of the abundance of Utermöhl plankton, plus the epifluorescence cell counts in the $2-5 \mu \mathrm{m}$ size class (chl a per $>2 \mu \mathrm{m}$ cell). This procedure was chosen because the organisms in the $2-5 \mu \mathrm{m}$ size group are strongly underestimated by inverted microscope techniques. The $<2 \mu \mathrm{m}$ cells (Synechococcus spp. and $<2 \mu \mathrm{m}$ phytoplankton) were not included because, although they represented more than $90 \%$ of the total cell counts, their contribution to the total volume of autotrophic organisms was only about $10 \%$ (Delgado et al. 1992). Obviously, using cell numbers instead of cell volumes can generate an unrealistic interpretation of the data if there are large differences in mean cell sizes. Nevertheless, in the studied stations, there was no indication of dominance of any particular size class (of the $>2 \mu \mathrm{m}$ groups) at specific depths in the water column (Delgado et al. 1992). Hexanoyl concentration was related to the number of $2-10 \mu \mathrm{m}$ organisms, which were assumed to comprise mainly prymnesiophytes. This was an oversimplification; however, because of the dominance of Phaeocystis sp. in this group, we considered that the results could be meaningful. Fucoxanthin concentration was related to the combined abundance of diatoms and silicoflagellates. To account for the contribution of Phaeocystis sp., which presents fucoxanthin as a minor pigment (Wright \& Jeffrey 1987), a correction was carried out subtracting from the measured fucoxanthin concentration a value derived from considering a hexanoyl : fucoxanthin $(\mathrm{W}: \mathrm{W})$ ratio $=10.7$ (Wright \& Jeffrey 1987, mean of their data for 3 Phaeocystis strains). Zeaxanthin concentration was related to the number of Synechococcus cells isee the 'Results' section, concerning the possible contribution from other groups). Another pigment marker found in detectable quantities was alloxanthin, typical of the cryptomonads, but also present in the ciliate Mesodinium rubrum, which contains symbiotic cryptomonad-like chloroplasts (Gieskes \& Kraay 1983); nevertheless, the counts of those organisms were too low and erratic to be used in a ratio.

Statistical analysis. Principal component analysis (PCA) was used to summarize the information contained in the phytoplankton taxa and pigment composition data sets, which included 57 and 40 samples respectively (Cooley \& Lohnes 1971, Legendre \& Legendre 1984). A total of 44 phytoplankton taxa (see Table 1) and 18 pigments were selected for the analysis on the basis of frequency of appearance in the samples. Calculations were performed on the correlation matrix among the selected variables after a logarithmic transformation of the abundance or concentration data.

The correlation between the sum of concentrations of phaeophorbides $a_{1}, a_{2}$ and $a_{3}$ (hereafter referred to as 'phaeophorbide' concentration), mesozooplankton nitrogen and ciliate concentration was assessed by means of the Spearman's rank correlation coefficient (Siegel 1956). Samples from 0 and $20 \mathrm{~m}$ were not considered to exclude the presumably intense effect of phaeopigment photooxidation at these levels (SooHoo \& Kiefer 1982a, b, Welschmeyer \& Lorenzen 1985).

\section{RESULTS}

Sections of temperature and salinity along the studied transect are shown in Fig. 3. The Catalan front was located at the shelf break, between Stns B-3 and B-4. Although an upper layer of warm waters masked the surface thermal signature of the front, its location could be clearly seen in the distribution of salinity in the deeper waters (Fig. 3). The described situation is typical for the Northwestern Mediterranean Sea during the stratification period (Font et al. 1988, Estrada \& Salat 1989). Between Stns B-2 and B-5, the nitracline coincided approximately with the isohaline at $38.2 \%$.

Profiles of photon flux density of PAR (photosynthetically active radiation) at the studied stations are given in Fig. 4. Values at the DCM depth (Fig. 5) ranged from 82 to $16 \mu \mathrm{E} \mathrm{m}^{-2} \mathrm{~s}^{-1}$ (ca 4 to $0.8 \%$ of those at surface).

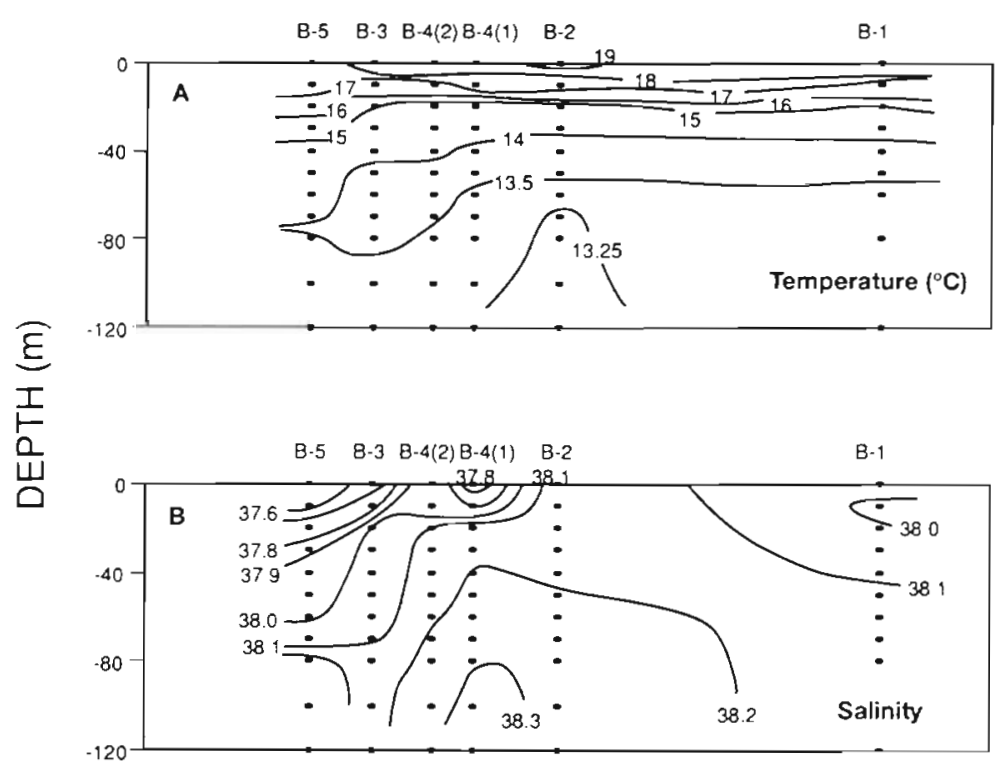

Fig. 3. (A) Temperature and (B) salinity profiles at the sampling stations 


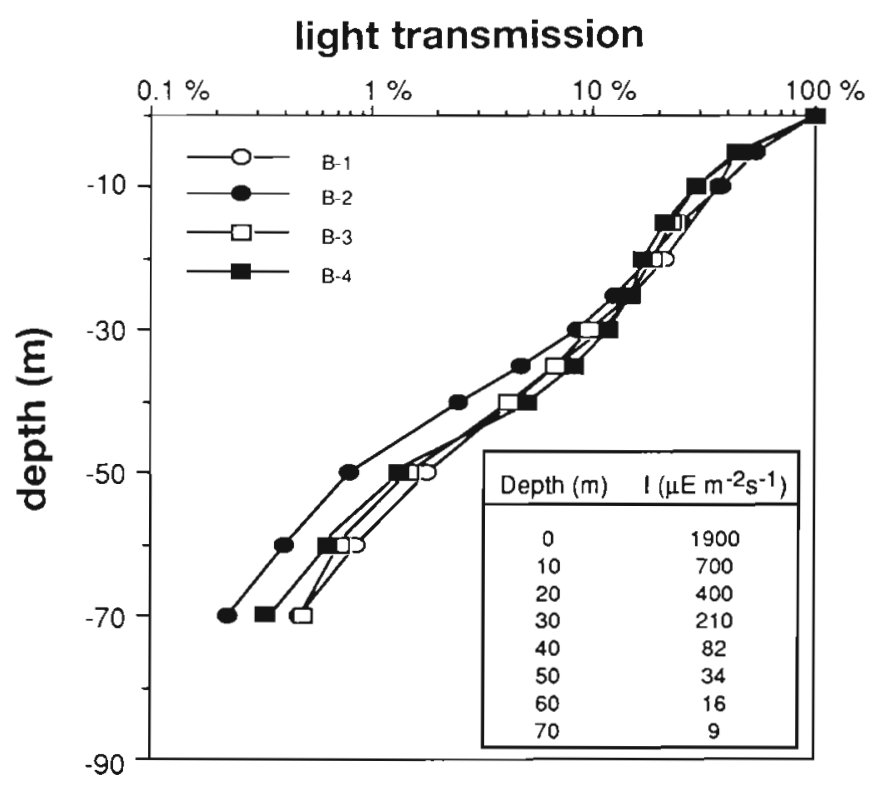

Fig. 4. Light profiles as percentage of surface irradiance and irradiance values of Stn B-1

\section{Pigment and plankton distributions}

Chl a concentrations (Fig. 5) presented a marked maximum (DCM) between 40 and $50 \mathrm{~m}$ depth, with values exceeding 2 nmol $1^{-1}$ at Stns B-2 and B-3. The DCM coincided approximately with the cell number maximum and with the nitracline. In addition to chl $a$ and chl $c$, several pigments with well-known chemotaxonomic meaning were found in measurable amounts: fucoxanthin (diatoms and chrysophytes: Jeffrey 1974), hexanoyl (prymnesiophytes: revised by Wright \& Jeffrey 1987), alloxanthin (cryptophyceae: Gieskes \& Kraay 1983), zeaxanthin (cyanobacteria: Guillard et al. 1985; prochlorophytes: Chisholm et al. 1988) and chl b (green algae: Lorenzen 1981; prochlorophytes: Chisholm et al. 1988). All these pigments except alloxanthin, which was present in the upper euphotic zone, presented a maximum at the DCM level. Chl a, hexanoyl (the major carotenoid in the area) and component 1 of the pigment PCA, which reflected total pigment abundance patterns (see below), presented a similar distribution (Fig. 5).

The HPLC technique revealed only traces of peridinin, although the inverted microscope observations showed that small dinoflagellates were present throughout the water column. It is likely that many of these organisms were heterotrophic as hypothesized by Jeffrey \& Hallegraeff (1987), who made a similar observation. In addition, it should be noted that, to our knowledge, peridinin has not been found in significant amounts in oceanic natural samples of mixed populations containing dinoflagellates, although part of them should have been presumably autotrophic. It could be that, in certain conditions, this pigment is only produced in small amounts.

The distribution of Utermöhl plankton, $2-10 \mu \mathrm{m}$ epifluorescence phytoplankton and Synechococcus spp. (Fig. 6) presented a maximum at $70 \mathrm{~m}$ depth in the inshore station (B-5) and between 40 and $50 \mathrm{~m}$ depth in the others. The spatial distribution of diatoms (Fig. 6) presented a high concentration patch in the frontal zone. The most abundant diatom taxa were several species of Chaetoceros, Rhizosolenia and Thalassiosira. Phaeocystis sp. was the dominant form in the $2-10 \mu \mathrm{m}$ epifluorescence fraction, which showed also a deep maximum (Fig. 6). The silicoflagellates Dictyocha fibula and $D$. speculum were more abundant at depth,
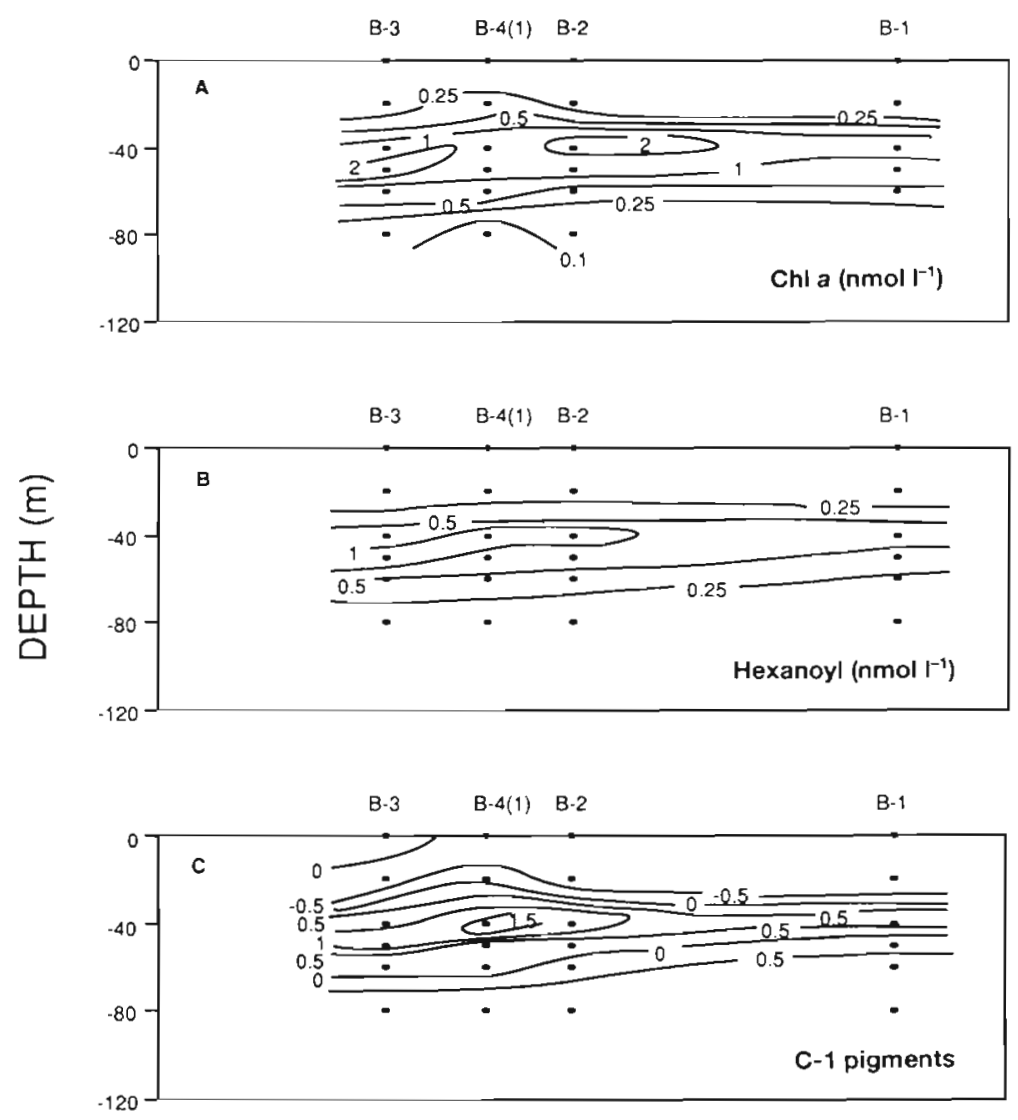

Fig. 5. Distribution of (A) chl $a_{1}$ (B) $19^{\prime}$ hexanoyloxyfucoxanthin (hexanoyl) and $(C)$ Component 1 of pigment PCA 

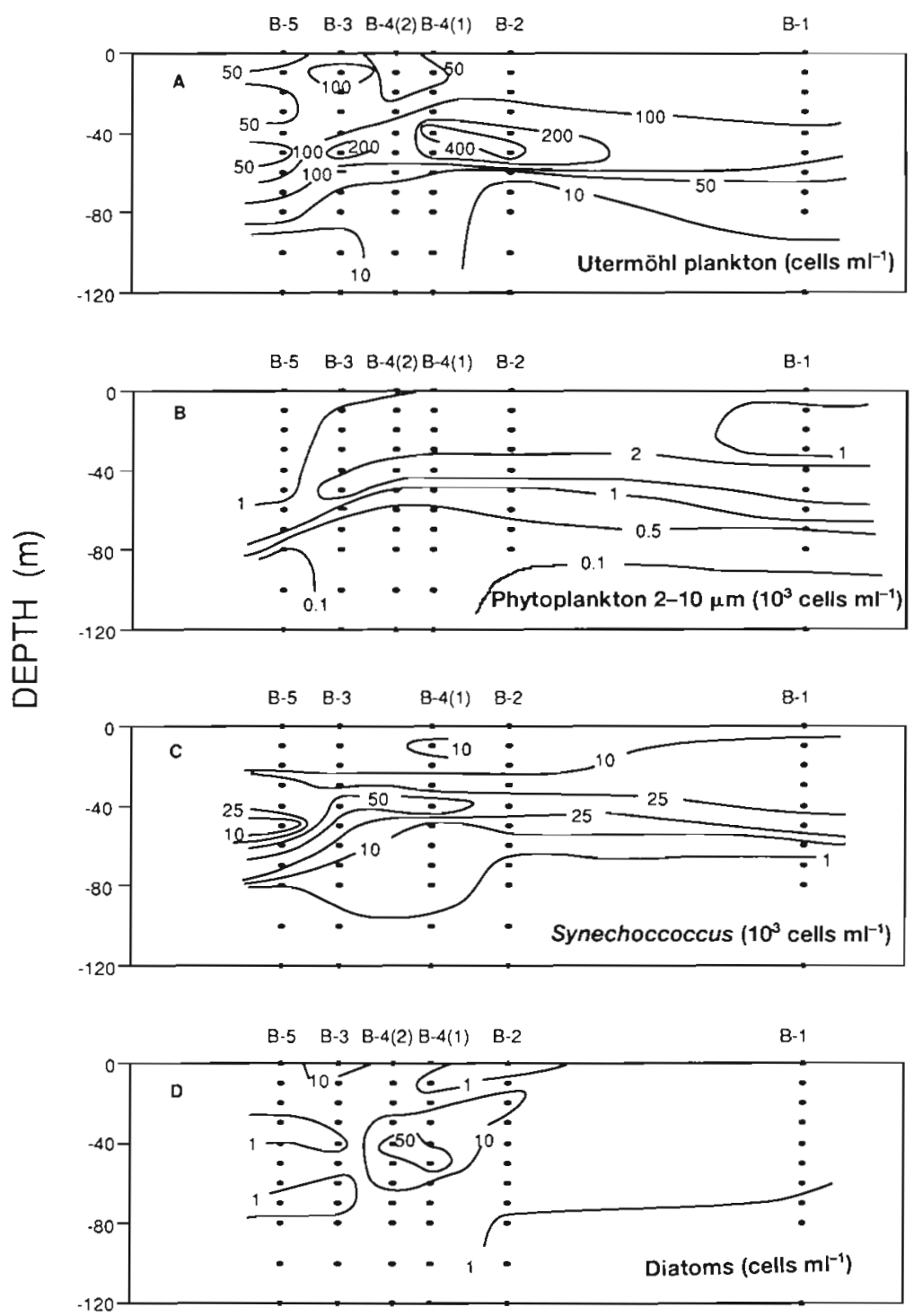

Fig. 6. Distribution of (A) Utermöhl plankton (inverted microscope technique), (B) 2-10 $\mu \mathrm{m}$ size phytoplankton (epifluorescence microscopy), (C) Synechococcus spp. (epifluorescence microscopy) and (D) diatoms (inverted microscopy)

although their numbers (data not shown) did not exceed a few cells per ml.

\section{Phaeophorbide calculations}

Significant correlations were found between phaeophorbide concentration and mesozooplankton biomass (Spearman's rank correlation coefficient: $0.68, p<0.01$ ), but not between phaeophorbides and ciliate abundance. The grazing rate derived from the equation of Welschmeyer \& Lorenzen (1985) for Stn B-4(1) at 40 m depth was $0.013 \mathrm{~d}^{-1}$. The estimated amount of phaeophorbides contained in mesozooplankton organisms was $1.1 \mathrm{pmol} \mathrm{l}^{-1}$.

\section{Pigment:cell ratios}

The concentration of chl a per $>2 \mu \mathrm{m}$ cell showed a marked increase between 20 and $60 \mathrm{~m}$ depth (Fig. 7). Hexanoyl per 2-10 $\mu \mathrm{m}$ cell and non-Phaeocystis fucoxanthin per diatom + silicoflagellate cell presented similar profiles (Fig. 7). In contrast, zeaxanthin appeared to accumulate in Synechococcus spp. of the shallower levels (Fig. 7). Our methods were not adequate to identify prochlorophytes, which could also contribute to the zeaxanthin peak. Prochlorophytes, which contain chl $a$, chl $b$ and zeaxanthin as major pigments (Burger-Wiersma et al. 1986, Chisholm et al. 1988), have been reported to be widespread in oligotrophic waters, including the Northwestern Mediterranean (Gieskes et al. 1988, Li \& Wood 1988, Olson et al. 1990, Vaulot et al. 1990) However, the relatively low levels of chl $b$ recorded suggest that prochlorophytes, chlorophytes or prasinophytes were not major components of the autotrophic plankton (Gieskes \& Kraay 1989) in our samples.

\section{Principal component analysis}

The first component of the pigment PCA was positively correlated with all pigments (Fig. 8) and its distribution reflected the increased concentration of most of them at the level of the DCM (Fig. 5). The second component (Figs. 8 \& 9) reflected the accumulation of degradation pigments (phaeophorbides $a_{1}, a_{2}, a_{3}$ ) near the frontal zone (Fig. 9), coinciding with a peak of mesozooplankton biomass (Fig 9). The third component (Figs. 8 \& 10) expressed a contrast between the pigment composition in the upper part of the water column, with relatively higher proportions of alloxanthin and zeaxanthin, and in the lower levels of the euphotic zone, with relatively higher proportions of fucoxanthin and one of the phaeophorbides.

The first 3 components of PCA analysis with the Utermöhl phytoplankton explained 27.8, 12.0 and $8.3 \%$ of variance respectively. As usually found in similar studies, the first component was positively correlated with most taxa, and represented an overall measure of phytoplankton abundance. The second component (Table 1, Fig. 10) expressed an opposition between several taxa, mostly of diatoms (Thalassiosira 

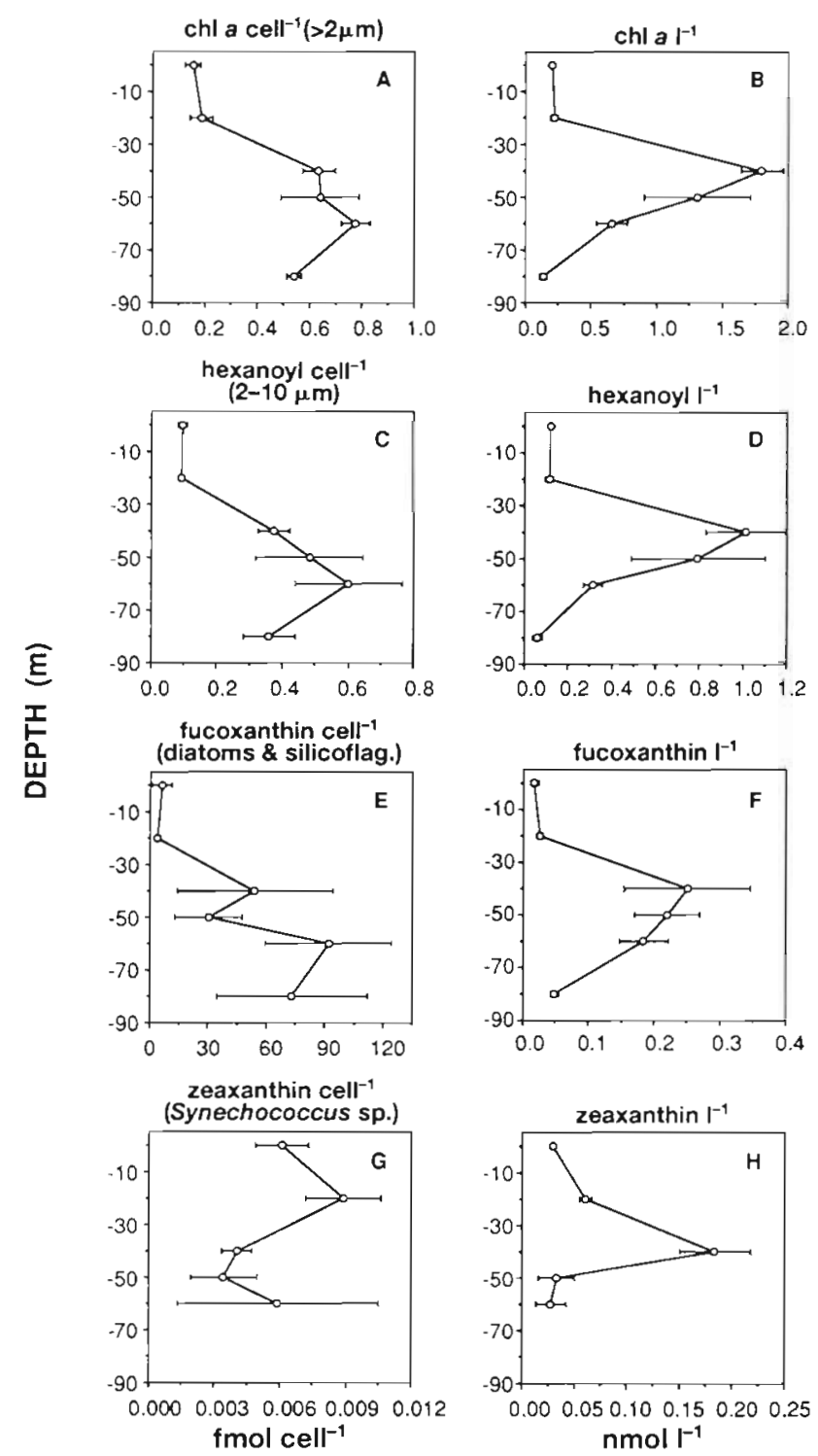

Fig. 7. Distribution of: (A) chl a per cell $(>2 \mu \mathrm{m})_{i}$ (B) chl a concentration; (C) 19' Hexanoyloxyfucoxanthin per cell $(2-10 \mu \mathrm{m})$; (D) 19' Hexanoyloxyfucoxanthin concentration; (E) fucoxanthin per cell (diatom + silicoflagellate); (F) fucoxanthin concentration; (G) zeaxanthin per cell Synechococcus spp.; $(\mathrm{H})$ zeaxanthin concentration. The data are the average of the 4 stations $\pm \mathrm{SE}$

eccentrica, Pleurosigma sp., unidentified pennate diatoms, Coscinodiscus sp., Hemidiscus cuneiformis, etc.), which were abundant in the lower euphotic zone, on one side, and a group of large dinoflagellates (Prorocentrum micans, Prorocentrum spp., Ceratium furca, C. fusus, C. declinatum, etc.), which were typical of the upper layers, on the other. The third component (data not shown) reflected differences in taxonomic composition between the 2 offshore stations and the remaining ones.
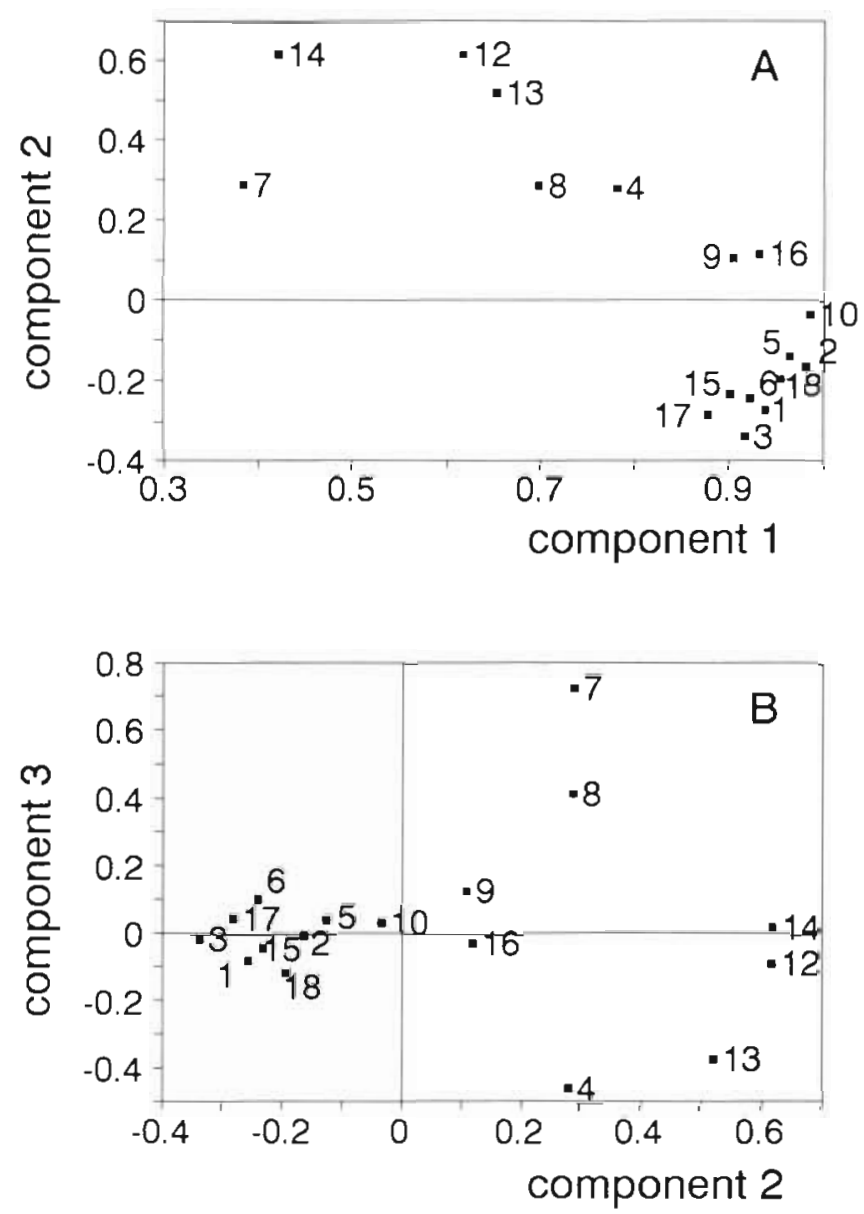

Fig. 8. Positions of the extremes of the 18 pigment vectors in the space determined by (A) the first and second principal components and $(B)$ the second and third principal components. Pigment identification: 1 to 11 as in Fig. 2; (12) chl a; (13) phaeophorbide $a_{1 i}$ (14) phaeophorbide $a_{2 i}$ (15) phaeophorbide $a_{3 i}(16) \mathrm{chl}$ a allomer; (17) chl a isomer; (18) unknown

\section{DISCUSSION}

The marked maximum of autotrophic plankton and photosynthetic pigments found between $40 \mathrm{~m}$ and $60 \mathrm{~m}$ depth (Figs. 4 \& 5) is typical of the stratification period in the area and has been reported in previous surveys carried out during the same period of the year (Estrada 1985, Estrada \& Margalef 1988, Estrada \& Salat 1989). The diatom and mesozooplankton patches centred around Stn B-4 (Figs. 6 \& 9) coincided with high rates of primary production (E. Berdalet \& $\mathrm{M}$. Estrada unpubl.). This peculiarity suggests the occurrence of a pulse of biological activity at this location, presumably as a result of nutrient input into the euphotic layer. Although difficult to record, intermittent fertilization pulses (Goldman 1988), due to hydrographic perturbations in the frontal zone, may explain the presence of significant in situ growth in the 

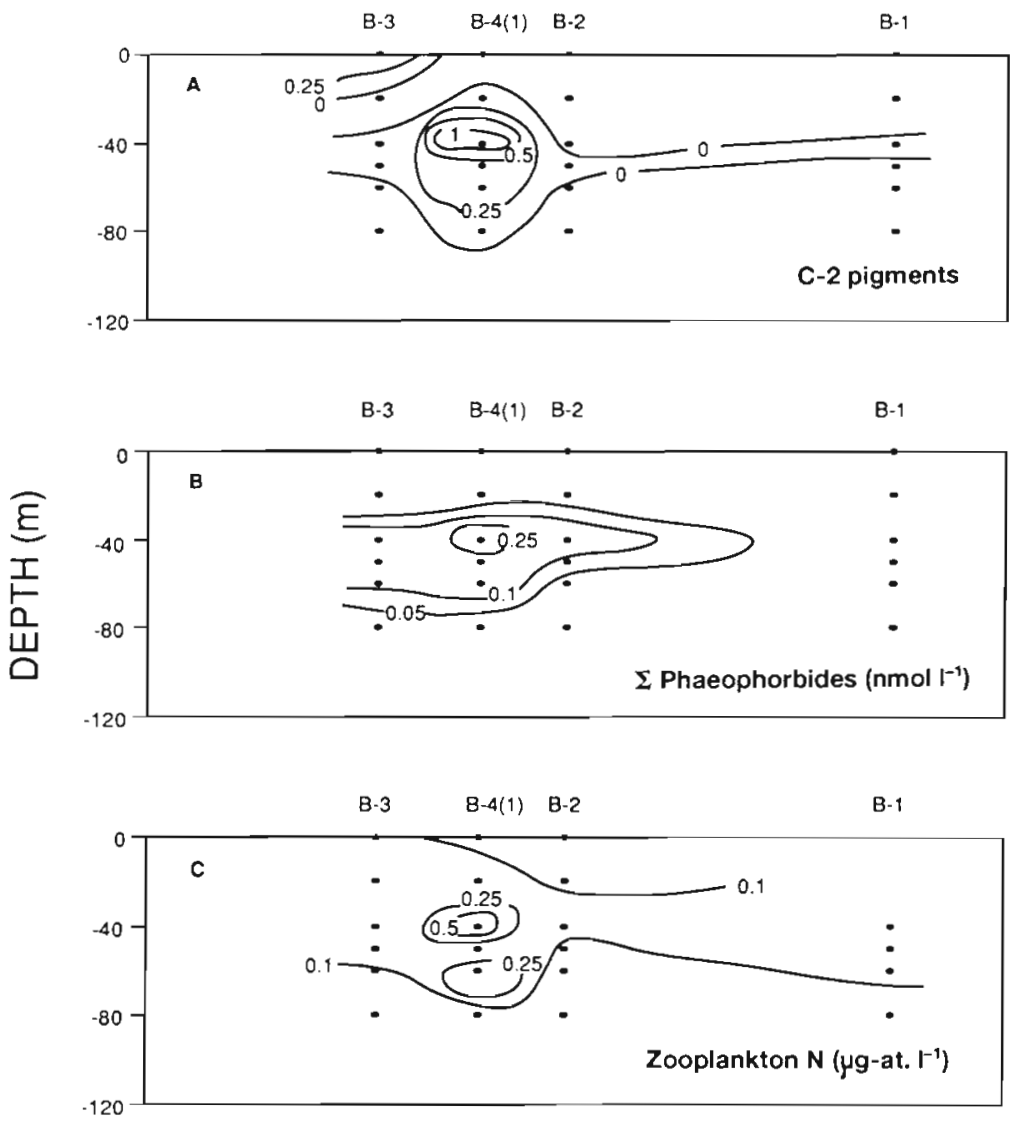

Fig. 9. Distribution of $(A)$ the second component of the pigment $P C A,(B)$ the concentration of phaeophorbide (phaeophorbide $a_{1}+$ phaeophorbide $a_{2}+$ phaeophorbide $a_{3}$ ), and (C) mesozooplankton biomass (in terms of $\mu \mathrm{g}$-at. $\mathrm{N} \mathrm{l}^{-1}$ )

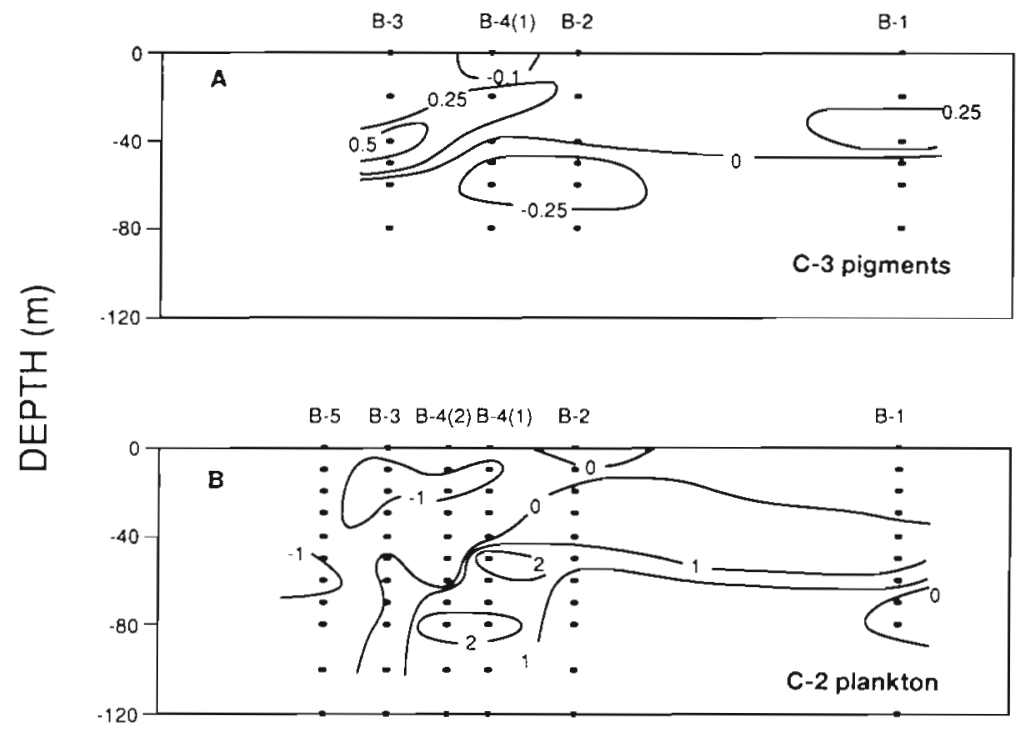

Fig. 1.0. Distribution of $(A)$ the third component of the pigment $P C A$, and (B) the second component of algal PCA phytoplankton populations of the DCM (Estrada 1985), and may represent an important contribution to the total primary production in the region.

The discussion of the results will be focused on 2 aspects: (1) the relationship between phaeopigment and mesozooplankton distribution, and (2) the relationship of pigment distributions with plankton taxonomy and physiology.

\section{Relationship between phaeophorbide concentration and zooplankton abundance}

The coincidence between the distribution patterns of phaeophorbides and mesozooplankton biomass (Fig. 9) seems to indicate an association between mesozooplankton activity (grazing) and the presence of phaeophorbides. We do not have data on the abundances of microzooplankton other than ciliates, but the lack of correlation between phaeophorbide and ciliate abundances, or between phaeophorbide and nanoplankton (a probable food source for microheterotrophs) distributions, suggests that neither these organisms nor their faecal debris were responsible for the observed phaeophorbide patterns. Nevertheless, a possible contribution of microheterotrophs to the phaeophorbide production cannot be discarded. Other possible sources of phaeophorbide, such as senescent phytoplankton cells, do not appear to be important in natural waters (Welschmeyer \& Lorenzen 1985, Guerrero et al. 1988) and, in our samples, the calculated amount of phaeophorbide inside the bodies of mesozooplankton organisms did not exceed $0.5 \%$ of the measured concentration. Thus, in our study area, it is likely that mesozooplankton faecal pellets may have been the main source of phaeophorbides in suspension. This does not agree with studies showing that macrozooplankton faecal pellets tend to sink rapidly and contribute little to the amount of phaeopigments in suspension (SooHoo \& Kiefer 1982a, Angel 1984). However, high concentrations of faecal debris in the water column, inconsistent with high sedimentation rates, have been recorded by 
Table 1. Utermöhl plankton taxa ranked by their loading on the second principal component (frequency data PCA)

\begin{tabular}{|c|c|c|}
\hline Rank & Taxon & Loading \\
\hline 1 & Thalassiosira eccentrica (Ehrenb.) Cleve & 0.71 \\
\hline 2 & Dictyocha speculum Ehrenb. & 0.63 \\
\hline 3 & Pleurosigma spp. & 0.63 \\
\hline 4 & Pennate diatoms (small) & 0.59 \\
\hline 5 & Torodinium sp. (small) & 0.47 \\
\hline 6 & Gyrodinium spp. & 0.47 \\
\hline 7 & Coscinodiscus sp. & 0.43 \\
\hline 8 & Protoperidinium spp. (small) & 0.43 \\
\hline 9 & Unidentified dinoflagellate $\mathrm{A}$ & 0.35 \\
\hline 10 & Hemidiscus cuneiformis Wallich & 0.34 \\
\hline 11 & Small dinoflagellates & 0.34 \\
\hline 12 & Coscinodiscus radiatus Ehrenb. & 0.33 \\
\hline 13 & Rhizosolenia fragilissima Bergon & 0.25 \\
\hline 14 & Rhizosolenia styliformis Brightw. & 0.24 \\
\hline 15 & Warnowiaceae (large) & 0.21 \\
\hline 16 & Haptophyceae (including Phaeocystis sp.) & 0.19 \\
\hline 17 & Thoracosphaera heimii (Lohmann) Kamptner & er 0.14 \\
\hline 18 & Dictyocha fibula Ehrenb. & 0.09 \\
\hline 19 & Nitzschia Pseudonitzschia) spp. & 0.09 \\
\hline 20 & Thalassiothrix sp. & 0.00 \\
\hline 21 & Ciliates & -0.03 \\
\hline 22 & Mesoporos perforatus (Gran) Lillich & -0.04 \\
\hline 23 & Rhizosolenia stolterfothii Peragallo & -0.09 \\
\hline 24 & Goniodoma polyedricum (Pouchet) Jörg. & -0.09 \\
\hline 25 & Goniodoma sphaericum Murray et Whitting & -0.10 \\
\hline 26 & Chaetoceros spp. & -0.10 \\
\hline 27 & Mesodinium sp. & -0.11 \\
\hline 28 & Unidentified dinoflagellate B & -0.13 \\
\hline 29 & Oxytoxum margalefi Rampi & -0.14 \\
\hline 30 & Warnowiaceae (small) & -0.15 \\
\hline 31 & Ceratium horridum & -0.17 \\
\hline 32 & Flagellates & -0.20 \\
\hline 33 & Helicosphaera carteri (Wallich) Kamptner & -0.22 \\
\hline 34 & Prorocentrum compressum (Bailey) Abe & -0.23 \\
\hline 35 & Rhizosolenia spp. & -0.23 \\
\hline 36 & Ceratium tripos (O. F. Müller) Nitzsch & -0.26 \\
\hline 37 & Rhizosolenia alata Brightw. & -0.28 \\
\hline 38 & Dinophysis sp. (56) & -0.39 \\
\hline 39 & Torodinium robustum Kofoid et Swezy & -0.42 \\
\hline 40 & Ceratium declinatum (Karsten) Jörg. & -0.42 \\
\hline 41 & Ceratium furca (Ehrenb.) Clap et Lachm. & -0.47 \\
\hline 42 & Ceratium fusus (Ehrenb.) Dujardin & -0.49 \\
\hline 43 & Prorocentrum spp. (small) & -0.53 \\
\hline 44 & Prorocentrum micans (Ehrenb.) & -0.59 \\
\hline
\end{tabular}

several authors (Krause 1981, Alldredge et al. 1987 , Bathman et al. 1987). Two possible mechanisms to explain this apparent paradox may be the occurrence of coprophagy and coprorhexy (breakage of faecal pellets due to feeding on them) carried out by certain copepods (Frankenberg \& Smith 1967, Lampitt et al. 1990, Noji et al. 1991). This behaviour would make faecal materials susceptible to physical and chemical destruction and would reduce their sinking rates.

The grazing rate of $0.013 \mathrm{~d}^{-1}$ derived from the equation of Welschmeyer \& Lorenzen (1985) is only a minimum value because phaeopigment losses are mini- mized by the assumptions of negligible sinking and total transformation of grazed chlorophyll into phaeopigments. Using a $\mathrm{C} / \mathrm{chl} a(\mathrm{w}: \mathrm{w})$ ratio of 30 (Delgado et al. 1992), the phytoplankton doubling time at Stn B-4(1), estimated from ${ }^{14} \mathrm{C}$ experiments (E. Berdalet \& M. Estrada unpubl.), would have been $1 \mathrm{~d}$. Thus, the calculated minimum grazing rate would have represented $1.9 \%$ of the primary production. Saiz et al. (1992), using a method based on gut clearance rates, calculated that mesozooplankton grazing at Stn B-4(1) consumed about $10 \%$ of the primary production. This result is consistent with our higher minimum estimate. However, these figures should be taken only as rough approximations, because both primary production and grazing rates are subjected to high spatial and temporal variability.

\section{Pigment distribution in relation with plankton taxonomy and physiology}

Both taxonomic and physiological differences contributed to the observed pigment distributions in the water column. The deep maxima of pigments such as fucoxanthin and hexanoyl appeared to result from the position of the population peaks of phytoplankton organisms containing them and from the increase in cellular concentrations at depth (Fig. 7). Peaks of diatom abundance at or below the DCM have been often reported in the Mediterranean and other areas (Estrada 1985); the association of diatoms with situations of enhanced primary production (Margalef 1978) suggests that there may be significant in situ growth at the DCM level. The distribution of alloxanthin in shallow levels of the water column reflected probably higher abundances of Mesodinium rubrum or of Cryptophyceae. According to previous observations, this last group has a preference for surface levels (R. Margalef pers. comm.). Similar observations were made in North Sea waters by Gieskes \& Kraay (1983), who reported that alloxanthin and fucoxanthin were found respectively at the surface and at the bottom of the euphotic zone.

It is interesting to note that the highest cell concentrations of pigments with a light harvesting function, like fucoxanthin or chlorophyll, were found below the peaks of maximum concentration in the water column (Fig. 7). An increase of the internal pigment concentration has been interpreted basically as a response to light-limited conditions in cultures (Beardall \& Morris 1976, Perry et al. 1981, Rivkin et al. 1982, Geider et al. 1985, Kana \& Glibert 1987), although it has not been always confirmed in natural populations (Rivkin et al. 1982, Morrow 1988). The observation that hexanoyl presents a behaviour similar to that of chlorophyll or 
fucoxanthin corroborates the photosynthetic role of this pigment (Haxo 1985).

Among the 4 pigment:cell ratios computed, only zeaxanthin: Synechococcus spp. showed a pattern of increased concentration in cells of shallower levels (Fig. 7). In higher plants, zeaxanthin has been described as a photoprotective pigment taking part in the violaxanthin cycle (Hager 1980). However, laboratory experiments with Synechococcus clone WH7803 have shown significant discrepancies in relation to the response of zeaxanthin to increasing irradiation (Kana et al. 1988, Bidigare et al. 1989). Despite the high variability encountered, which could be due in part to the presence of prochlorophytes, our results suggest an increase of the zeaxanthin content in Synechococcus spp. cells exposed to higher irradiances. This could not be accounted for by differences in cell size, which appeared to vary little in the studied samples (Delgado et al. 1992). The mean values of the zeaxanthin: cell ratio ranged from $0.0035 \mathrm{fmol}^{\mathrm{m}} \mathrm{cell}^{-1}$ (50 $\mathrm{m}$ depth) to $0.0061 \mathrm{fmol} \mathrm{cell}^{-1}$ (20 m depth) or 2.0 to $3.6 \mathrm{fg} \mathrm{cell}^{-1}$, in agreement with values of 1.8 and 2.9 to $6.8 \mathrm{fg} \mathrm{cell}^{-1}$ given by Kana et al. (1988) and Bidigare et al. (1989) respectively for Synechococcus clone WH7803. This strain could be dominant in the Catalan Sea as suggested by Algarra et al. (1988). It is interesting to note that the mean zeaxanthin : cell ratio varied only 2 -fold between cells under photon flux densities of less than $16 \mu \mathrm{E} \mathrm{m}^{-2} \mathrm{~s}^{-1}$ (irradiance at $60 \mathrm{~m}$ depth) and $1900 \mu \mathrm{E} \mathrm{m}^{-2}$ $\mathrm{s}^{-1}$ (irradiance at the surface). Although measurements of light quality were not made in our cruise, it appears that blue-green light (probably the dominant irradiance at depth; Kirk 1983) did not enhance zeaxanthin cell concentration. Thus, our results differ from those of the laboratory work of Kana et al. (1988) and Bidigare et al. (1989), who reported that zeaxanthin: cell increased only with changes in light quality. This discrepancy could, perhaps, be related to differences in nutrient availability, which affect the pigment concentration per cell (see below). In our study, the distribution of Synechococcus spp. cells, with a marked maximum associated with the nitracline, suggested nutrient limitation in the shallow waters. However, the increase of the internal concentration of zeaxanthin indicated that there was little or no limitation of the synthesis of this pigment by the cells. It can be speculated that zeaxanthin represents the last link of a metabolic route. A similar suggestion has been made for diatoxanthin, which appears to accumulate passively in starved phytoplankton cells in culture (Klein 1988, M. Latasa \& E. Berdalet unpubl.). Whether or not a passive effect, the accumulation of zeaxanthin by Synechococcus spp. in surface oligotrophic waters, subjected to high irradiation, could have a role in protection from photooxidative damage (Gieskes \& Kraay 1986).
The vertical profiles of the pigment:cell ratios (Fig. 7) suggest a well-defined structure of the water column and, in particular, of the DCM, which presents an upper part where irradiance is not strongly limiting to growth (Chan 1978), and a lower part where cells become light-stressed and do not adapt their pigment composition. Gieskes \& Kraay (1986) described comparable changes in relative pigment proportions within the $30 \mathrm{~m}$ comprising the DCM of the open tropical Atlantic. Below the DCM, at $>70 \mathrm{~m}$ depth in our study area, light levels (Fig. 4) were probably too low to supply the energy needed by phytoplankton to optimize the amount of pigment per cell. The discrepancy with observations of active growth of phytoplankton at irradiances lower than $2.5 \mu \mathrm{E} \mathrm{m} \mathrm{m}^{-2} \mathrm{~s}^{-1}$ in other studies (Geider et al. 1985 , 1986) may have been due to factors such as the species composition, the duration of the light-dark cycle or the effects of the light regime and other environmental conditions on respiratory losses.

The contrast between the upper and the lower part of the euphotic zone revealed by the PC-3 of the pigment PCA, which weighted on the one side zeaxanthin and alloxanthin, present in higher proportion at surface, and on the other fucoxanthin (Fig. 8), relatively more abundant at deeper levels, was also found in the distribution of the phytoplankton assemblages, as reflected in the distribution of the PC-2 of the phytoplankton PCA (Fig. 10). However, no direct correspondence can be established between the results of both analyses. While, for instance, the increment of fucoxanthin concentration at depth can be related to increased diatom abundance, many of the taxa accounting for the distribution of major pigments (such as Synechococcus spp. or the cryptomonads) could not be included in the phytoplankton PCA. The similarity of the distribution patterns of the phytoplankton $\mathrm{PC}-2$ and the pigment $\mathrm{PC}-3$ (Fig. 10) reflects the fact that the composition of the whole phytoplankton community, together with its associated pigments, is influenced by the ecological differences between the upper, nutrientlimited but well-illuminated water layers and the relatively nutrient-rich but poorly illuminated lower layers of the euphotic zone.

As discussed in the present study, the information given by pigment analysis reflects many different processes affecting phytoplankton, such as growth rate, grazing activity, and light or nutrient availability. The simplified view of the stratified water column in an oligotrophic sea, with a nutrient-depleted, well-illuminated upper compartment, and a deep chlorophyll layer associated with the nitracline, should be complemented with other aspects such as the heterogeneity of the DCM, the adaptation of certain taxa to different environmental situations, the contribution of the zoo- 
plankton to phaeopigment accumulation or the particular physiological response of the different pigments to the environmental conditions.

Acknowledgements. We thank all participants and crew of the RV 'Garcia del Cid' for their cooperative work during the FRONT 89 cruise. The authors are specially indebted to Dr E. Saiz and Dr M. Alcaraz for sharing their data, Dr C. Pedrós-Alió for his thorough revision of the manuscript. M. Palau for providing ciliate numbers and A. Cruz for technical assistance. The comments made by Dr S. W. Wright and 2 anonymous reviewers were used to improve the manuscript. M.L. was supported by an F.P.I. scholarship from the Spanish Government. This research was supported by the Comision Interministerial de Ciencia y Tecnología, MAR88-0252 project.

\section{LITERATURE CITED}

Abaychi, J. K., Riley, J. P. (1979). The determination of phytoplankton pigments by HPLC. Anal chim. Acta 107: $1-11$

Algarra, P., Estrada, M., Niell, X. (1988). Phycobiliprotein distribution across the western Mediterranean divergence. Deep Sea Res. 35: 1425-1430

Algarra, P., Vaqué, D. (1989). Cyanobacteria distribution across the Western Mediterranean divergence: a proof of pigment adaptation in different light conditions. Scient. Mar. 53: $197-202$

Anderson, G. C. (1969). Subsurface chlorophyll maximum in the Northeast Pacific Ocean. Limnol. Oceanogr. 14: 386-391

Angel, M. V. (1984). Detrital organic fluxes through pelagic ecosystems. In: Fasham, M. (ed.) Flows of energy and materials in marine ecosystems. Plenum Press, New York, p. $475-516$

Alldredge, A. L., Gotschalk, C. C., MacIntyre, S. (1987). Evidence for sustained residence of macrocrustacean faecal pellets in surface waters off southern California. Deep Sea Res. 34: 1641-1652

Båmstedt, U. (1986). Chemical composition and energy content. In: Corner, E. D. S., O'Hara, S. C. M. (eds.) The biological chemistry of marine copepods. Oxford Univ. Press, Oxford, p. 1-58

Banse, K. (1977). Determining the carbon-to-chlorophyll ratio of natural phytoplankton. Mar. Biol. 41: 199-212

Bathmann, U., Noji, T T., Voss, M., Peinert, R. (1987). Copepod faecal pellets: abundance, sedimentation and content at a permanent station in the Norwegian Sea in May/June 1986. Mar. Ecol. Prog. Ser. 38: 45-51

Beardall, J., Morris, I. (1976). The concept of light intensity adaptation in marine phytoplankton some experiments with Phaeodactylum tricornutum. Mar. Biol. 37: 377-387

Beers, J. R., Reid, F. M. H., Stewart, G. L. (1975). Microplankton of the North Pacific Central Gyre. Population structure and abundance, June 1973. Int. Revue ges. Hydrobiol. 60: 607-638

Bidigare, R. R., Schofield, O., Prézelin, B. B. (1989). Influence of zeaxanthin on quantum yield of photosynthesis of Synechococcus clone WH7803 (DC2). Mar Ecol. Prog. Ser. 56: $177-188$

Burger-Wiersma, T., Veenhuis, M., Korthals, H. J., Van De Wiel, C. C. C., Mur, L. R. (1986). A new prokaryote containing chlorophylls $a$ and $b$. Nature $320: 262-264$

Chan, A. T. (1978). Comparative physiological study of marine diatoms and dinoflagellates in relation to irradi- ance and cell size. I. Growth under continuous light. J. Phycol. 14: 396-402

Chisholm, S. W., Olson, R. J., Zettler, E. R., Goericke, R., Waterbury, J. B., Welschmeyer, N. A. (1988). A novel freeliving prochlorophyte abundant in the oceanic euphotic zone. Nature 334: 340-343

Cooley, W. W., Lohnes, P. R. (1971). Multivariate data analysis. John Wiley and Sons, New York

Cullen, J. J. (1982). The deep chlorophyll maximum, comparing vertical profiles of chlorophyll a. Can. J. Fish. Aquat. Sci. 39: 791-803

Delgado, M. Latasa, M., Estrada, M. (1992). Size-class distribution of autotrophic pico and nanoplankton across the Catalan Front (Northwest Mediterranean). J. Plankton Res. 14:753-771

Dugdale, R. C. (1967). Nutrient limitation in the sea: dynamics, identification and significance. Limnol. Oceanogr. 12: 685-695

Estrada, M. (1985). Deep phytoplankton and chlorophyll maxima in the Western Mediterranean. In: MoraitouApostolopoulou, M., Kiortsis, V. (eds.) Marine Mediterranean ecosystems. Plenum Press, New York, p. 247-277

Estrada, M., Margalef, R. (1988). Supply of nutrients to the Mediterranean photic zone along a persistent front. Oceanol. Acta $n^{\circ}$ spéc. 9: 133-142

Estrada, M., Salat, J. (1989). Phytoplankton assemblages of deep and surface water layers in a Mediterranean frontal zone. Scient. Mar. 53: 203-214

Font, J., Salat, J., Tintoré, J. (1988). Permanent features in the circulation of the Catalan sea. Oceanol. Acta 9:51-57

Foppen, F. H. (1971). Tables for the identification of carotenoid pigments. Chromat. Rev. 14: 133-298

Frankenberg, D., Smith, K. L. (1967). Coprophagy in marine animals. Limnol. Oceanogr. 12: 443-450

Furuya, K. (1990). Subsurface chlorophyll maximum in the tropical and subtropical western Pacific Ocean: vertical profiles of phytoplankton biomass and its relationship with chlorophyll a and particulate organic carbon. Mar. Biol. 107: $529-539$

Furuya, K., Marumo, R. (1983). The structure of the phytoplankton community in the subsurface chlorophyll maxima in the western North Pacific Ocean. J. Plankton Res. 5: 393-406

Geider, R. J., Osborne, B. A., Raven, J. A. (1985). Light dependence of growth and photosynthesis in Phaeodactylum tricornutum. J. Phycol. 21: 609-619

Geider, R. J., Osborne, B. A., Raven, J. A. (1986). Growth, photosynthesis and maintenance metabolic cost in the diatom Phaeodactylum tricornutum at very low light levels. J. Phycol. 22: 39-48

Gieskes, W. W. C., Kraay, G. W. (1983). Dominance of Cryptophyceae during the phytoplankton spring bloom in the central North Sea detected by HPLC analysis of pigments. Mar. Biol. 75: 179-185

Gieskes, W. W. C., Kraay, G. W. (1986). Floristic and physiological differences between the shallow and the deep nanophytoplankton community in the euphotic zone of the open tropical Atlantic revealed by HPLC analysis of pigments. Mar. Biol. 91: 567-576

Gieskes, W. W. C., Kraay, G. W. (1989). Estimating carbonspecific growth rate of the major algal species groups in the eastern Indonesian waters by ${ }^{14} \mathrm{C}$ labelling of taxonspecific carotenoids. Deep Sea Res. 36: 1127-1140

Gieskes, W. W. C., Kraay, G. W., Nontji, A., Setiapermana, D., Sutomo (1988). Monsoonal alternation of a mixed and a layered structure in the phytoplankton of the euphotic zone of the Banda Sea (Indonesia): a mathematical 
analysis of algal pigment fingerprints. Neth. J. Sea Res. 22 $123-137$

Gieskes, W. W. C., Kraay, G. W., Tijssen, S. B. (1978). Chlorophylls and their degradation products in the deep pigment maximum layer of the tropical North Atlantic. Neth. J. Sea Res. 12: 195-204

Goldman, J. C. (1988). Spatial and temporal discontinuities of biological processes in pelagic surface waters. In. Rothschild, B. J. (ed.) Toward a theory on biologicalphysical interactions in the world ocean., NATO ASI Ser. (C) Math. phys. Sci.), No. 239. Kluwer Academic Publ., Dordrecht, p. 273-296

Guerrero, F., Rodríguez, V., Bautista, B., Jiménez-Gómez, F (1988). Procesos de formación y pérdida de feopigmentos en sistemas pelágicos: evaluación en condiciones de laboratorio. Inv. Pesq. 52: 437-449

Guillard, R. R. L., Murphy, L. S., Foss, P., Liaaen-Jensen, S. (1985). Synechococcus sp. as likely zeaxanthin dominant ultraphytoplankton in the North Atlantic. Limnol. Oceanogr. 30: 412-414

Hager, A. (1980). The reversible, light-induced conversions of xanthophylls in the chloroplast. In: Czygan, F. C. (ed.) Pigments in plants. Fischer, Stuttgart, p. 57-79

Haxo, F. T (1985). Photosynthetic action spectrum of the coccolitophorid Emiliania huxleyii Haptophyceae): 19' hexanoyloxyfucoxamthin as antenna pigment. J. Phycol. 21: $282-287$

Herbland, A., Voituriez, B. (1979). Hydrological structure analysis for estimating the primary production the tropical Atlantic Ocean. J. mar. Res. 37: 87-101

Hobson, L. A., Lorenzen, C. J. (1972), Relationships of chlorophyll maxima to density structure in the Atlantic Ocean and Gulf of Mexico. Deep Sea Res. 19: 297-306

Jeffrey, S. W. (1974). Profiles of photosynthetic pigments in the ocean using thin-layer chromatography. Mar. Biol. 26: $101-110$

Jeffrey, S. W., Hallegraeff, G. M. (1980). Studies of phytoplankton species and photosynthetic pigments in a warm core eddy of the East Australia Current. II. A note on pigment methodology. Mar. Ecol. Prog. Ser. 3: 295-301

Jeffrey, S. W., Hallegraeff, G. M. (1987). Phytoplankton pigments, species and light climate in a complex warm-core eddy of the East Australian Current. Deep Sea Res. 34: $649-673$

Kana, T M., Glibert, P. M. (1987). Effect of irradiances up to $2000 \mu \mathrm{E} \mathrm{m}^{-2} \mathrm{~s}^{-1}$ on marine Synechococcus WH 7803. I. Growth, pigmentation and cell composition. Deep Sea Res. 34 479-495

Kana, T M., Glibert, P. M., Goericke, R., Welschmeyer, N. A. (1988). Zeaxanthin and B-carotene in Synechococcus WH 7803 respond differently to irradiance. Limnol. Oceanogr. 33: $1623-1627$

Kuefer, D. A., Olson, R. J., Holm-Hansen, O. (1976). Another look at the nitrite and chlorophyll maximum in the Central North Pacific. Deep Sea Res. 23: 1199-1208

Kirk, J. T O. (1983). Light and photosynthesis in aquatic ecosystems. Cambridge Univ. Press, Cambridge

Klein, B. (1988). Variations of pigment content in two benthic diatoms during growth in batch cultures. J. exp. mar. Biol. Ecol. 115: 237-248

Krause, M. (1981). Vertical distribution of fecal pellets during FLEX '76. Helgoländer Meeresunters. 34: 313-328

Lampitt, R. S., Noji, T., von Bodungen, B. (1990). What happens to zooplankton faecal pellets? Implications for material flux. Mar. Bıl. 104: 15-23

Legendre, L., Legendre, P. (1984). Ecologie numérique. Masson, Paris
Li. W. K., Wood, A. M. (1988). Vertical distribution of North Atlantic ultraphytoplankton: analysis by flow cytometry and epifluorescence microscopy. Deep Sea Res. 35: $1615-1638$

Lorenzen, C. J. (1981). Chlorophyll $b$ in the eastern North Pacific Ocean. Deep Sea Res. 28: 1049-1056

Mantoura, R. F. C., Llewellyn C. A. (1983). The rapid determination of algal chlorophyll and carotenoid pigments and their breakdown products in natural waters by reversephase high-performance liquid chromatography. Anal. chim. Acta 151: 297-314

Margalef, R. (1978). Life-forms of phytoplankton as survival alternatives in an unstable environment. Oceanol. Acta 1: 493-509

Margalef, R., Herrera, J., Steyaert, M., Steyaert, J (1966). Distribution et caractéristiques des communautés phytoplanctoniques dans le bassin tyrrhérien de la Méditerranée en fonction des facterus ambiants et à la fin de la stratification estivale de l'année 1963. Bull. Inst. r. Sci. nat. Belg. 42: 1-56

Morrow, J. H. (1988). Light absorption in naturally occurring marine phytoplankton communities. Ph.D. dissertation, Univ. Southern California, Los Angeles

Noji, T. T., Estep, K. W., MacIntire F, Norbin F. (1991). Image analysis of faecal material grazed upon by three species of copepods: evidence for coprorhexy, coprophagy and coprochaly. J. mar. biol. Ass. U.K. 71: 465-480

Olson, R. J., Chisholm, S. W., Zettler, E. R., Altabet, M. A., Dusenberry, J A. (1990). Spatial and temporal distributions of prochlorophyte picoplankton in the North Atlantic Ocean. Deep Sea Res. 37: 1033-1051

Ondrusek, M. E., Bidigare, R. R., Sweet, S. T., Defreitas, D. A., Brooks, J. M. \{1991\}. Distribution of phytoplankton pigments in the North Pacific Ocean in relation to physical and optical variability. Deep Sea Res. 38: 243-266

Perry, M. J., Talbot, M. C., Alberte, R. S. (1981). Photoadaptation in marine phytoplankton: response of the photosynthetic unit. Mar. Biol. 62: 91-101

Rivkin, R. B., Seliger, H. H., Swift, E., Biggley, W. H. (1982). Light-shade adaptation by the oceanic dinoflagellates Pyrocistis noctiluca and $P$. fusiformis. Mar Biol. 68: $181-191$

Rowan, K. S. (1989). Photosynthetic pigments of algae Cambridge Univ. Press, Cambridge

Saiz, E., Rodríguez, V., Alcaraz, M. (1992). Spatial distribution and feeding rates of Centropages typicus in relation to frontal zones in the Catalan Sea (Western Mediterranean). Mar. Biol. 112: 49-56

Siegel, S. (1956). Nonparametric statistics. McGraw-Hill Kogakusha Ltd., Tokyo

SooHoo, J. B., Kiefer, D. A. (1982a). Vertical distribution of phaeopigments. I. A simple grazing and photooxidative scheme for small particles. Deep Sea Res. 29: 1539-1551.

SooHoo, J. B., Kiefer, D. A. (1982b). Vertical distribution of phaeopigments. II. Rates of production and kinetics of photooxidation. Deep Sea Res., 29: 1552-1563

Takahashi, M., Hori, T (1984). Abundance of picophytoplankton in the subsurface chlorophyll maximum layer in subtropical and tropical waters. Mar. Biol. 79: 177-186

Taniguchi, A., Kawamura, T (1972). Primary production in the Oyashio region with special reference to the subsurface chlorophyll maximum layer and phytoplankton-zooplankton relationships. In: Takenouti, A. Y., Anraku, M., Banse, K., Kawamura, T., Nishizawa, S., Parsons, T R., Tsujita, T. (eds.) Biological oceanography of the Northern North Pacific Ocean. Idemitsu Shoten, Tokyo, p. 231-244 
Utermöhl, H. (1958). Zur Vervollkommnung der quantitativen Phytoplankton Methodik. Verh. int. Verein. theor. angew. Limnol. 9: 1-38

Varelä, R., Grup Fronts (in press). Datos oceanográficos básicos de las Campañas FRONTS 1989, FRONTS 1990 y FRONTS 1991 en el Mar Catalán. Datos Informativos Institut de Ciències del Mar, Barcelona

Vaulot, D., Partensky, F., Neveux, J., Mantoura, R. F. C. Llewellyn, C. A. (1990). Winter presence of prochlorophytes in surface waters of the northwestern Mediterranean Sea. Limnol. Oceanogr. 35: 1156-1164

Venrick, E. L., McGowan, J. A., Mantyla, A. W. (1973). Deep

This article was submitted to the editor maxima of photosynthetic chlorophyll in the Pacific Ocean. Fish. Bull. U.S. 71: 41-52

Welschmeyer, N. A., Lorenzen, C. J. (1985). Chlorophyll budgets, zooplankton growth in a temperate fjord and the Central Pacific Gyres. Limnol. Oceanogr. 30: 1-21

Wright, S. W., Shearer, G. D. (1984). Rapid extraction and high-performance liquid chromatography of chlorophylls and carotenoids from marine phytoplankton. J. Chromatogr. 294: 281-295

Wright, S. W., Jeffrey, S. W. (1987). Fucoxanthin pigment markers of marine phytoplankton analyzed by HPLC and HPTLC. Mar Ecol. Prog. Ser. 38: 259-266

Manuscript first received: January 27, 1992

Revised version accepted: September 9, 1992 